\title{
GENDER, GREEDY INSTITUTIONS AND THE DEPARTMENTAL COURT
}

Fiona Mackay and R. A. W. Rhodes

\section{Introduction}

Feminist scholarship and public administration engage with each other but infrequently. The wider public administration literature seldom addresses gender questions (Miller and McTavish 2010). We seek to direct the attention of feminist political scientists away from the parliamentary arena and women's policy agencies as the main sites for studying gender politics to a focus on the executive in British government (Annesley and Gains 2010). Our concern is to identify, map and understand the ways in which the everyday beliefs and practices of British central government departments - or specifically their 'departmental courts'- are gendered. We revisit Rhodes's (2011) analysis of daily life in British central government departments using a gender lens to uncover how constructions of masculinity and femininity are enacted through everyday practices, and with what gendered consequences. We draw on three organising ideas - departmental courts, greedy institutions and gendered bureaucracies. We argue that the departmental courts are greedy institutions and, as a result, women are constrained to manage like men.

This article takes as its starting point an insight on which both neo-institutionalist scholars (Streeck and Thelen 2005) and interpretive scholars (Bevir and Rhodes 2010) can agree: the need to understand the daily workings of institutional life. How are institutions (whether understood as rules of the game or as sedimented practices) of public administration or governance made and remade daily by institutional actors, and with what consequences? We argue that it is important to map and examine the 'inner life' of an institution and the ways in which beliefs and practices confront change to understand and 
explain the continuity of particular patterns of beliefs and actions. We argue these patterns are gendered.

Government departments are 'gendered' organizations in that they embed certain constructions of masculinity and femininity in their everyday beliefs and practices that shape 'ways of valuing things, ways of behaving, and ways of being' (Duerst-Lahti and Kelly 1995, 20). This conception is in marked contrast with the idea of gender relations and gendered norms as 'existing out in society or fixed within individuals, which they then bring whole to the institution' (Kenney 1997, 456). Rather, gender is understood as a constitutive element of social relations based on perceived (socially constructed and crossculturally variable) differences between women and men. It operates at the subjective and interpersonal level through which humans identify themselves and organize their relations with others. It is also embedded in practices and the symbolic realm of meaning-making; in the webs of significance which individual actors spin (Hawkesworth 2005: 143-145; Scott 1986). One of the key ways in which gender works is through dichotomies whereby the social world is understood through the association of masculinity and femininity with particular attributes and values. The values and attributes associated with masculinity (such as strength, rationality, activity) are counterposed with a set of opposites (such as weakness, empathy, passivity), which are coded as feminine. These associations go far beyond presumed character traits to operate as a more general organising frame. So, for example, in much Western political thought and wider societal stereotypes, the public sphere is seen as masculine and the private sphere as feminine; culture is associated with the masculine and nature with the feminine; authority and leadership with masculinity and deference and subordination with femininity (Hooper 2001, Sjoberg 2013). Gender provides an important means by which particular, often unequal, arrangements come to be seen as naturalized or institutionalized. Gender thus provides a lens for analyzing 
sedimented beliefs and practices and the differential outcomes of distributional contests and discursive struggles.

\section{$\underline{\text { The departmental court }}$}

What do we mean by the departmental court? British government departments are headed by an elected politician known as the Secretary of State (or Minister). He or she is assisted by junior ministers, referred to here as Ministers of State, who are elected but appointed to their ministerial post by the Prime Minister. The top official in the department is known as the Permanent Secretary. Private Offices support both Ministers and permanent secretaries. Civil servants staff both offices. A principal private secretary (PPS), who will be a young civil servant expecting rapid promotion, heads each office. The Private Office controls the diary, prepares and collates the papers, and ensures that the Minister turns up at meetings on time and fully prepared. In these tasks, they work with the department's functional directorates, headed by a Director-General (DG). Taken together, these officials comprise a small elite group who work closely with the elected politicians.

Rhodes (2011) argues that this team should be seen as the departmental executive. Ministers have a support system comprising more than the Minister's Private Office and his or her Principal Private Secretary (PPS). Commonly, it also includes ministerial or special advisers (SpAds) who have their own Private Secretary (PS); the Private Offices of Ministers of State; the Permanent Secretary's Private Office, and some permutation of Parliamentary, Correspondence, and Business Support units. So, one department had eight ministers and about 80 people supporting them. Rhodes argues that is more accurate to talk of a 'departmental court' because of the hierarchical and monarchical traditions of government departments, which give rise to 
recognisable court politics surrounding ministers and senior civil servants, to the competition between ministers, and to the tensions within the court and with the rest of the department and between civil servants and SpAds.

\section{Gendered bureaucracy}

The feminist analysis of bureaucracy stresses that rather than being neutral, the defining characteristics of bureaucracy have gendered foundations and consequences. These characteristics are hierarchical organization, the division of labour, and technical rationality (Ferguson 1984; Yeatman 1990; Stivers 2002). The culturally dominant beliefs and practices of masculinity are associated with instrumental, goal-oriented behaviour; referred to as the 'cultural masculinization of authority' (Franzway et al 1989). Femininity is associated with emotional and relational activities. As Ramsay and Parker (1992: 262265) observe, while both embody rationality, task oriented rationality is valued more than relational in bureaucratic hierarchies. So, bureaucracies embed gendered values and rewards, most notably the symbolic association of men and masculinity with the practices of control and authority, and the devaluing of the beliefs and practices culturally and historically associated with femininity, for example, empathy and cooperation. Masculinity is associated historically with specific beliefs and practices and this inherited dominant managerial style shapes the beliefs and practices of both men and women.

We agree with Billing's (1994, see also Britton 2000) critique of this literature that there is a need for a nuanced portrait of bureaucracy. Bureaucracies are historically gendered in ways which tend to privilege men and specific sorts of masculinity but that need not imply that bureaucracies are inherently gendered, always gendered in the same way or always produce similar gendered consequences such as differential access and reward (Britton 2000; Stivers 2002). As Stivers notes, by asserting that the dominant ideas and values of 
bureaucracies are masculine does not imply that all men embody these characteristics or that such masculinities are monolithic. Rather, it is argued that certain historically specific constructions of masculinity become 'hegemonic' - limiting the beliefs and practices against which others are measured and measure themselves. Hegemonic masculinity constrains and restricts men as well as women but, in general, these underlying beliefs and practices with their implicit performance standards carry a greater cost and cause greater disadvantage to women (Connell 2005; Stivers 2002). The continued public private divide, 'limits both women's opportunities to participate in public life and the time and energy they have to devote to it.' (Stivers 2002:4)

So, we seek to tease out the gendered assumptions and consequences of the everyday practices of a specific bureaucracy - the departmental courts at the heart of UK government. How do bureaucratic rules, practices and beliefs reflect and reproduce (unequal) gender relations? What are the gendered consequences of everyday practices in the departmental courts at the top of British government, for example do they disadvantage women?

\section{Greedy institutions}

The metaphor of 'greedy institutions' provides another useful building block for exploring the gendered departmental court. Coser $(1974,4)$ suggests that 'greedy institutions':

seek exclusive and undivided loyalty and attempt to reduce the claims of competing roles`and status positions on those they wish to encompass within their boundaries. Their demands on the person are omnivorous. 
Although the idea was developed in the study of trade unions, it has obvious relevance to the senior civil service - and ministerial office - which, similarly, rely on voluntary compliance, loyalty, trust and commitment from its members. As Watson (1994) notes, there is an informal 'code of ethics of the selfless civil/public servant' in which there is a strong normative dimension to the conventions of long hours, loyalty, and prioritization of work above all other commitments (see also Stivers 2002; and for public bureaucracies more generally, see Bird 2011; Kelly et al. 2011).

We use the metaphor of the 'greedy institution' to refer to the web of beliefs and practices in government bureaucracies around the primacy of loyalty and trust, and particularly around selfless commitment and long hours' culture.

Franzway (2001, 33-4) developed the concept to highlight the problems greedy institutions pose for women at work, particularly given the unequal division of caring labour that still predominates in most societies. Greedy institutions can be understood as gendered because the total commitment required (long hours, privileging of work over social and intimate relationships, family and social life) comprises a form of 'heroic masculinity’ (see, for example, Bellavita 1991; Terry 1991; Stivers 2002). This notion assumes there are others taking care of care (including care of the hero); and devalues care work and relationships; it is predicated on and reinforces a breadwinner-homemaker model.

For women it presents a double bind in which they are expected to be as committed to their work as male counterparts, while managing the practical costs of caring responsibilities, and being 'normatively required to give priority to their family' (Coser 1974, 94; see also Martin 2006; Stivers 2002). Women, especially mothers, are still in the position where they are less likely to live up to the inherited beliefs and 
practices of the bureaucracy. They are, therefore, less likely to be perceived as high performers (Stivers 2002) or to accrue the benefits associated with being a 'good' worker (Kelly et al. 2011) in greedy institutions.

\section{The Gendered Bureaucracy and the Greedy Court}

The beliefs and practices that comprise the gendered bureaucracy and 'greedy court' include hierarchy and bureaucratic politics; civility, rationality and managing emotions; gendered patterns of work; and loyalty and commitment as displayed by the long hours' culture. We examine the way these features play out in the everyday practices of the departmental court. We ask how things are done around here? We seek to tease out the gendered consequences and costs of these practices.

\section{The data and the fieldwork}

The data are drawn from Rhodes's (2011) ethnographic study of three British government departments in the 2000s looking at everyday life at the top. It is worth emphasising that a unique feature of this study is its focus on the governmental elite, the apex, not the front line. He examined the beliefs and everyday practices of elected ministers and their top officials or permanent secretaries to understand the form and extent of changing models of leadership and governance (see also Bevir and Rhodes 2003, 2006, 2010). He examined the protocols, rituals and practices through which the status quo was preserved, dilemmas managed, and coping strategies deployed to survive the frenetic daily life at the apex of government; dynamic conservatism in the service of willed ordinariness. In doing so, he identified the resilience of the traditional Whitehall model of government despite encroachments from the competing narratives and practices of managerialism and network governance. 
While providing important insights, the original study was not concerned with how gender might play out in these dynamics, and with what consequences. We reanalysed the reported data, the original transcribed interviews (TIs) and the fieldwork note books (FWNB) by applying a gender lens. This analysis reveals new understandings of the traditions and practices of actors in departmental courts. Unlike surveys, which are limited by the specific questions asked, ethnographic research is exploratory - 'unstructured soaking' (Fenno 1990, 57). It is characterized by deep immersion in social worlds so we can understand day-to-day practices, and how these practices become meaningful. So, it lends itself to reanalysis wearing a different set of spectacles. However, there are challenges when trying to uncover beliefs and practices, and their gendered consequences; there are gaps and silences. The relative lack of senior women as civil servants and ministers, and their uneven distribution, pose practical problems. The interviews and fieldwork observations were for citation but not for attribution; preserving anonymity makes it difficult to undertake systematic comparison and fine-grained analysis of, for example, male and female career trajectories or interdepartmental differences. Indeed, to preserve anonymity in the original study, Rhodes used the masculine pronoun in reporting data on ministers and permanent secretaries, and collapsed the three departments into one composite 'court'.

A further issue for ethnographic approaches - which are principally about understanding the daily world of actors on their own terms - is that the daily practices of gender (and the beliefs underpinning such practices) are often unthinking rather than purposive. Actors may not see the gendered consequences of daily practices because of the taken-for-granted quality of gender relations and bureaucratic beliefs and practices (Martin 2006, Stivers 2002). The question arises of whether observation and interviews will uncover and analyse 
pervasive social relations such as gender. Of course, much will depend on the skills of the observer, and ethnographic fieldwork, like any other research method in the social sciences, has its strengths and weaknesses.

There is little point in trying to pretend that ethnography is just a 'soft' version of the positivist approach with its penchant for 'hard' quantifiable data. It is different in both the aims and knowledge criteria employed. In his defence of case studies, Flyvbjerg (2006: 224) argues 'concrete, context-dependent knowledge is ... more valuable than the vain search for predictive theories and universals'. He argues for the primacy of 'thick descriptions' (Geertz 1973). We agree that 'thick descriptions' produce data that is as valid as that of any social survey. Neither method is any better than the research question it seeks to answer. Ethnographic methods are well suited to answering questions about the embedded everyday beliefs and practices of the departmental court. Rhodes et al (2007: chapter 9) discuss the pros and cons of observation as a research tool for studying government elites at some length.

Rhodes's (2011) account is based on three sources of information (practice, talk, and considered writing) gathered during the second Blair parliament from 2001-2005. On practice, he observed the office of two ministers and three permanent secretaries for two days each, totalling some 120 hours. He also shadowed two ministers and three permanent secretaries for five working days each, totalling some 300 hours. On talk, he had repeat interviews with: ten permanent secretaries $(2 \times 2$-hour taped and transcribed), five secretaries of state and three ministers (1 x 2-hour taped and transcribed); and twenty other officials ( $1 \times 1$-hour taped and transcribed), totalling some 67 hours of interviews. On considered writing, he had copies of speeches and public lectures; committee and other papers relevant to the meetings observed; and 
newspaper reports. The interviews and fieldwork observations were for citation but not for attribution without the interviewee's permission. All interview quotes are from a taped and transcribed interview (TI) and identified by the position held by the individual - Minister, Permanent Secretary, and so on. For the quotes from Ministers there are eight possible sources, and for permanent secretaries there are ten. In every other case, there will be at least three possible sources for the quote. The 35 interviewees included three female elected ministers (two secretaries of state and a minister of state), three female senior civil servants (Permanent Secretary, deputy secretary and PPS) and eleven other female officials. There were so few senior women that if we gave the person's sex, in effect, we identified them. Most quotes are from women.

The fieldwork took place in three Departments similar in size and status, so we can talk about the composite Minister, Department, or Permanent Secretary and remains plausible: the Department for Education and Skills (DfES), the Department for Environment, Food \& Rural Affairs (DEFRA), and the Department of Trade and Industry (DTI). The interviews took place in 2002. The fieldwork was carried out in 2003. There were several repeat interviews and occasional visits in 2004. Following the established practice of latter-day ethnographers, the research is an example of 'yo-yo fieldwork'; that is, moving back and forth, in and out of the field (Wulff 2002, 117). The analysis also draws on several insider accounts of the period now available (see for example, Michael Barber 2007, Alastair Campbell 2007, and David Blunkett 2006). Throughout, whether drawing on fieldwork or other primary sources, we stress the views of insiders because we are trying to describe their world through their eyes. Throughout, we use dialogue, or reciprocal conversations, sometimes in the form of semi-structured, transcribed interviews but also, during the 
observational fieldwork, they were part of everyday conversations at the office (see Rhodes 2011 for a full account of study; and see Bevir and Rhodes 2003, 2006, 2010 on their interpretive approach.)

\section{Gender and the 'departmental court'}

How are the institutions of the departmental court lived and enacted daily? In this section, we describe the everyday practices associated with bureaucracy (hierarchy and bureaucratic politics; civility, rationality and managing emotions; gendered patterns of work) and greedy institutions (loyalty and commitment as demonstrated through long hours' culture). The aim is to highlight the ways in which, and with what consequences, gender is constructed, shaped, and maintained through beliefs and practices of the departmental court.

\section{$\underline{\text { Hierarchy and the monarchical tradition }}$}

It is a central tenet of feminist scholarship that masculinity is strongly associated with hierarchical authority structures in many organizations (Martin 2006). This association is particularly strong in political organizations and bureaucracies (Lovenduski 1998, Savage and Witz 1992). It is argued that gender is practiced in political institutions where men hold most of the most powerful positions and most women are subordinate to men in the formal authority structure, mirroring wider societal patterns of unequal gender relations (Sjoberg 2013). It remains a commonplace observation that the everyday life of the 'departmental courts' is still about the interactions of 'overwhelmingly middle-aged, white, university-educated men' (Bevir and Rhodes 2006, 111). This profile persists despite the long-standing formal commitment to promoting equal opportunities and to targets increasing the number of women and members of ethnic minorities in upper grades and the 
senior civil service (Watson 1994; Annesley and Gains 2010). The departmental court constitutes gender as white, male and middle class and, therefore, as we argue below, imposes significant constraints on female civil servants and ministers seeking to act on an equal footing in their daily work.

Government departments embed culturally hegemonic masculine beliefs and practices, which privilege hierarchical relationships of domination and subordination, which in turn map onto cultural associations of masculinity and femininity respectively (Stivers 2002, Savage and Witz 1992). The hierarchy of bureaucracy is further reinforced by the monarchical tradition, which persists as a central characteristic of the Westminster model and ministerial practice in British government. Ministers are the public face of government. They represent its authority. The Minister is the Queen's Minister and accorded due homage. The Minister is called Minister or Secretary of State and rarely addressed by his or her first name by officials. Outsiders display equivalent verbal and physical deference. He or she is the centre of attention and this simple fact is displayed in language, beliefs and practices. Most ministers dress to reinforce the appearance of rule. As a celebrity, the minister is escorted everywhere in a chauffeur driven car, greeted at doorways and on red carpets by respectful hosts.

Hierarchy pervades every aspect of everyday life. We can take, for example, the protocol concerning the ministerial telephone pecking order: 'the more junior minister rings and waits to be put through to the senior minister. Senior ministers wait for no one on the phone other than the Prime Minister. The Prime Minister waits for nobody'. Whenever you hear the phrase, 'Do you want to put your minister on and I'll put him through', you know the hierarchy protocol has been invoked. The departmental courts, like the rest of the civil service, are highly stratified and hierarchical, with clear lines of reporting and command. 
While informal practices of gossip and humour (see Rhodes 2011, Chapter 7) are used to express dissent, blow off steam, or 'cut people down to size', this does not undermine the chain of command or dilute loyalty to those at the apex of the power structure: the Minister and the Permanent Secretary. Loyalty is viewed as non-negotiable.

In seeking to understand the ways in which hierarchy has gendered consequences, we turn our attention to three aspects of bureaucracy: bureaucratic politics; civility, rationality and managing emotions; and gendered patterns of work

\section{$\underline{\text { Bureaucratic politics }}$}

Explicit discussions of gender and ideas about appropriate gender relations were not part of the original fieldwork. Despite that we see evidence that the culture of the departmental court is imbued with competitive masculinity both in the language and practices of bureaucratic politics, and their underlying beliefs. The hierarchical silos of government departments foster competition. Bureaucratic politics is conceived as 'turf wars' rather than cooperation. Officials from different departments attending meetings were 'seen, even described, as 'strangers' (Rhodes 2011, 182). Turf warfare is never far away. The following example will suffice:

The Minister stands over my desk and says, 'I want you ring up [the PPS], and said, 'I want you to pass a message to [your Minister] which is 'get your tanks off my lawn'. So I pick up the phone and I said, with [my Minister] standing there, 'Are you going to stand there?' And he said, 'Yes. I want you to pass that message on.' So I pick up the phone and I get [the PPS] and I said, 'I am going to give you a message to pass on to your Secretary of State and you have to pass it on without any elaboration'. 'And just to be clear, my Secretary of State is standing beside me 
as I give you this message and it is from my Secretary of State to your Minister, “get your tanks off my lawn”. ' [Permanent Secretary, TI; see also Lodge and Rogers 2006: 44-5]

Militaristic metaphors like those above are strongly associated with dominant forms of masculine authority and are commonly used to present and describe the practice of departmental courts by both insiders and commentators. For example, Norton (2000, 1167) argues, 'Ministers are like medieval barons in that they preside over their own, sometimes vast, policy territory' and like barons they are supported by their court as they 'fight - or form alliances - with other barons in order to get what they want' and they 'resent interference in their territory by other barons and will fight to defend it'.

While overt displays of aggression are discouraged by the conventions of "polite behaviour' (see later discussion), nonetheless there are frequent non-verbal displays of culturally masculine dominance by ministers and senior civil servants in committee meetings. Thus, the body language expressed self-confidence, aggression and control. Many (both men and women) spoke with a polite voice and a harsh body.

Competitiveness is illustrated by such displays of controlled aggression, the use of military metaphors to describe encounters with other departments, and the turf wars of bureaucratic politics. Such practices are strongly associated with dominant forms of bureaucratic and political masculinities (Stivers 2002; Lovenduski 1998). Confrontation is equated with masculinity and therefore strength. Cooperation or consensus is equated with femininity and is, therefore, weaker (Duerst-Lahti and Kelly 1995). Thus, the practices of bureaucratic politics are constrained by these embedded gendered beliefs and practices about what constitutes authoritative action (Franzway et al 1989; Sjoberg 2013). The consequences for 
all in the departmental court and particularly senior women are that actions are measured against these gendered criteria (see later discussion of Estelle Morris).

\section{Civility, Rationality and Managing Emotion}

Life in a departmental court is frenetic, unpredictable, stressful and tense. Rhodes discovered that a key daily task of the departmental court is to cope. Coping is not a dramatic activity. It is surprisingly ordinary. Private Offices exist to 'domesticate' trouble, to defuse problems; and take the emotion out of a crisis. Confronting a major issue with a public corporation, the Permanent Secretary commented, 'Thank you, a good way of cheering me up'. Everyone smiled. The style of the permanent secretaries was low key.

Everyday emotions such as anger, fear, disappointment, aggression, and conflict are also managed through understatement, detachment and the ritualized practices of politeness. Civility is an important but unremarked ritualized means of coping - and a mechanism of ruling. Politeness 'presupposes [the] potential for aggression as it seeks to disarm it, and makes possible communication between potentially aggressive parties' (Fox 2004: 97). Norms of civility mask hierarchies of power and privilege elite insiders.

Norms of civility are also gendered in that they are an expression of masculine bureaucratic rationality, in which emotion (of self and others) is controlled, and detachment is prized. These are preeminent traits of bureaucratic masculinity, practiced by both high status men and women. Conversely, expressions of emotion are culturally associated with femininity and viewed as weak and suspect (Stivers 2002; Young 1987).

Politeness governs most workplace encounters. So, most meetings start with a discussion of the weather and general enquiries about one's health, journey to work and, of course with cups of tea or coffee. The most common way of dealing with anger is to become cold. 
We came across variations of the phrase, 'He was one of those quietly icy men' [DS, TI]. 'It's a kind of withdrawal and coldness' [PPS, TI]. The following scene would be typical of the departments. The Permanent Secretary is 'mild'. It would be 'unacceptable' for him to swear. If something goes wrong, the PS will 'confess' that she lost the papers and the Permanent Secretary will 'sigh'. Then 'you know you've been ticked off' [PS, FWNB]. Anger is managed by politeness; by detachment, not swearing.

An effective way of unearthing such language codes is to explore events where they are breached. In the civil service the code of civility or politeness is breached by anger and by swearing.

Consider the following scene. At an internal budget meeting, a DG lost his temper. His section was suffering the largest budget cuts. He wanted a strategic review of base spending and his colleagues did not. He is excited, short of breath and he raises his voice. His body language is stiff, angular. His colleagues stare at the table and avoid eye contact. Some try to suggest compromise solutions but they all involve cuts. It is clear he is getting nowhere so he leaves the meeting. Everybody was embarrassed by this outbreak. The event was described as the Department 'at our worst'. The DG was 'OTT' and the meeting was 'hard work'. No one thinks the DG should have lost his temper. It would have been better if he had been 'disappointed'. He had breached the civility code. [FWNB]. The Permanent Secretary apologized for this behaviour all the way back to his office from the meeting. It simply wasn't done. Overt aggression was discouraged by the almost mandatory conventions of polite behaviour. People do not run, they do not shout, and they do not express overt emotion. Points are made politely. There are few if any cries of 'rubbish', and even expostulations are expressed mildly. All defer to the Chair. Remarks are 
addressed to others through the Chair. This scene prompted an extended reflection from one civil servant.

Your bit about language and part about anger/aggression and civility/politeness caused a great big lightbulb to flash on over my head. 33 years in the Civil Service, I hadn't connected it all up. I knew, of course, that a refusal to speak the management lingo marks you as an outsider - and I've certainly annoyed an awful lot of senior people in this way over the past 20 years. But I hadn't connected that to the typical senior civil servant's awkwardness about people issues, and their fear of anger and emotion. Years ago I went to a meeting at the (then) DES at which some clot said: 'You lot really care about this, don't you?' He seemed aghast. We did such was the leadership and the urgency and the importance of our task. As the son of a soldier (who probably should have been one himself), I'm mostly polite but have lost my temper a few times - only with senior people which I thought was OK. I realised reading your paper that this plus emotional commitment plus language differences has damaged an awful lot of my professional relationships with senior civil servants, with whom I've long had a problem. It all suddenly fell into place (personal communication, 8 August 2009).

Here a male civil servant was speaking, but one who regarded himself as still an outsider after more than 30 years in the service. His remarks resonate with Chappell's (2006) analysis of the norm of bureaucratic neutrality demonstrating that it is profoundly gendered, in terms of its cultural association with specific forms of masculinity, which disadvantages women - and men - who do not live up to the dominant norm. The norm of neutrality and emotional detachment limits the repertoire of skills and responses for dealing with any situation. It renders enthusiasm, frankness, advocacy and appearing to 
'care' as suspect and unprofessional in part because of the cultural association of emotion with femininity. If you do not conform, then you court the danger of being marginalized. It is also the case that the more the norm of 'neutrality' is embedded and enforced, the harder it will be for reformers to advance what will be perceived as 'biased' claims of gender equality (Chappell 2006, Stivers 2002).

\section{Gendered division of work}

While bureaucracies are seemingly detached and depersonalized, they require emotional work, including 'taking care of' work in order to function, although such work is often invisible, subordinate and gendered (Savage and Witz 1992). The Diary Secretary - who manages and coordinates the appointments of ministers and senior civil servants and 'smoothes their day'- is a good example of 'taking care of' work in the departmental court.

So are ministerial drivers and messengers who come bearing the 'ritual comfort of a cup of tea'. The work is gendered, and of low standing in the official hierarchy, conventionally carried out by women and lower status men.

The Diary is managed by Diary Secretaries (DS), sometimes nowadays called Diary Managers. They are key players in maintaining 'willed ordinariness' and managing 'rude surprises'. They regulate access to the Minister and the Permanent Secretary. The diary rules, so the DS is in a nodal position. As one PS observed:

I've always thought, from the minute I started in Private Office, the Diary Secretary is probably the most important person in that office because if the diary is wrong the whole day collapses.[PS, TI]

The minister agrees: 
I wanted a Diary Secretary who was not just well organized and efficient and could plan out my day [...], but also somebody who was effective and good at dealing with officials right across the Department because the job of a Diary Secretary is to get the material together that you need for whatever the event is that you're going to go to. [Minister, TI]

The Diary Secretaries play a pivotal role as gatekeepers and 'authorities' on the preferences of 'their' ministers but their status is ambiguous: the work is valued informally but is not officially high status, and the unofficial authority of the position is derived from and reinforces traditional gender roles. Some have high informal standing. One DS was not managed by the PS but reported directly to the Permanent Secretary. A key part of the job is to protect the Minister and Permanent Secretary.

I can't stand this old-fashioned thing of being the 'lion at the gate' or the 'gatekeeper'; it sounds so archaic. But I suppose that's the way it is. But [the Assistant Diary Secretary] and I tend to have an unwritten rule that we are the people that make the changes to the diary (emphasis in original) [DS, TI]

So, they redirect calls to other members of the Department, delay appointments pending consultation, and even fake entries to discourage requests [FWNB].

The Diary Secretary functions as, in the words of Rosemary Pringle (1989), the 'Office Wife' in a relationship that blurs boundaries between professional and personal services (see also Kanter 1977). The job is not limited to the diary and scheduling. She - we never met a male DS - also smoothes the Minister's day. 
I see that as important because if [the Minister] is not happy or if it's not done the way he wants it and it doesn't fit with him, you know, it will change. So, I will do double the work on that sort of thing. [DS, TI]

So the DS is the authority on Ministerial preferences both minor - for example, sandwiches - and major - no more than two dinner engagements a week. She will tell the partner whether it is black tie or lounge suit, short cocktail or long dress. As one PPS commented with some venom, 'the [Diary Secretary] is the authority on the [Permanent Secretary]'. [PPS, FWNB]

Most DSs try to help the Private Secretaries by:

giving them an idea of what [the Permanent Secretary] would like and not like, and pre-empting any problems and if they say this is the way to do it, I will say no he won't like it that way, you know, it's best to do it this way. [DS, TI]

One Diary Secretary used to pin on the Permanent Secretary's medals when he changed into formal wear at work. Another DS described herself as 'Mrs Fix It' because she did odd jobs like arranging for the Permanent Secretary's home phone to be repaired. On the one hand they keep order and train up novice private secretaries, but they also take shorthand, order sandwiches and arrange home maintenance. Some DSs had been in post for twenty years. Some moved with their Minister and Permanent Secretary. They know what he or she wants before he or she wants it.

These boss-secretary relations are characterized by several 'patrimonial' features. The first characteristic is status contingency, whereby the secretary derives her status not from her formal rank but from her boss. Second, the relationship displays principled arbitrariness, or no boundaries to managerial discretion so secretaries are at the beck and call of bosses 
and called on to carry out domestic and personal as well as professional tasks. Finally, the relationship demands fealty, which refers to the expectation of unquestioning personal loyalty from secretaries to their bosses, who in turn treat them as part of their personal 'estate' expecting emotional labour and rewarding them with non-material benefits such as ‘appreciation’ (Kanter 1977; Savage and Witz 1992).

While some argue that such boss-secretary relations are a 'relic' (Kanter 1977), others view them as integral to bureaucracies and the gendering assumptions on which they are built and continue to function (Pringle 1989; Savage and Witz 1992; Stivers 2002). These typical relationships were strongly in evidence in the fieldwork, and there were few signs that the role of Diary Secretary was undergoing significant change. Such embedded relationships and their daily practice are a key mechanism of coping and imposing 'willed ordinariness'. They also provide powerful reinforcement for the gendered status quo in which care work is associated with inherited beliefs about femininity and, while seen as necessary work, is not valued for professional recognition or reward in the bureaucracy. Diary secretaries, like most women workers in public administration, are 'on tap but not on top' (Stivers 2002:14). Such practices are replicated even when female ministers and senior civil servants are benefiting from the services of their Diary Secretaries.

The disjunction between official status and unofficial standing can fuel resentment based on gender and rank. It is telling that one respondent, a Diary Secretary, complained using a gendered metaphor, that the senior civil servants she worked with were hierarchal and grade conscious, treating 'the rest of us as mere minions and scullery maids of the office'.

\section{Commitment and the long hours' culture}

Promoting women to top positions in politics and the bureaucracy has not generally been 
matched by a rethinking of managerial work and the constraints under which it is done. So, women are obliged to conform to a traditionally masculine long hours' culture - 'with profound implications for relationships, homes, and conceptions of self' (Martin 2006; Kelly et al 2011, Wacjman 1999). All departmental courts were greedy institutions with an entrenched culture of long hours; a demonstration of commitment and loyalty.

It's the culture of the office. You can't, you couldn't, it's so busy, the volume of business within the office, you couldn't work on a 9-5 basis. You just couldn't. [DS, TI]

A long hours' culture is not gender neutral in that it is premised on others taking care of care, and assumes the primacy of work over other parts of life (Stivers 2002, Savage and Witz 1992, Kelly et al 2011).

The expectation and practice of long hours have costs for ministers and civil servants, both male and female.

when I was up here before it was stressful and I remember when, just before Christmas, I went home and I was very upset because I just found it so stressful and people had been ringing me up and had been talking in this rapid way to me about things I didn't understand - it was always stressful. I was always aware that if I got something wrong it would be damaging, it would be embarrassing, people would shout. [PPS, TI]

Some suffer physical side effects.

I find I will have physiological reactions to the stress sometimes. I will have weeks where I will have awful skin and my heart rate doesn't want to go down. Yesterday 
it was [the Minister] being in a bad mood. And that's stressful just because the service element of the job comes in. None of us knew how to make him feel better about his day. [PS, TI]

When we asked about their social life, the responses were almost identical:

Social life? I have not lost friends, but I have friends who are exhausted with saying, 'Let's go out Wednesday.' and me saying, 'Yes' and ringing them up 20 minutes before we are to go out saying, 'It's absolutely no way I can make it to the cinema. Absolutely no way.' [PS, TI]

I mean that's the worst side of it, I mean you 'pack in' a social life [PS, TI]

There is none [PPS, TI]

For members of the Private Office it is hard to strike a decent work-life balance, which accounts for a brisk turnover of staff. Commitment demonstrated through long working hours is not a formal requirement but is a powerful informal 'rule'. It has consequences for all, but can have differential consequences on the careers of female civil servants. We note that serving time in departmental private offices is a standard part of the career path of fast stream civil servants, typically in their late twenties and thirties. This age is also a stage in women's lives when they may plan to start families, or already have caring responsibilities. Thus, the gendering practices of the departmental court as a greedy institution presents extra obstacles to female civil servants' career trajectories and creates more burdens for individual women.

\section{The gender consequences of a greedy court}


Do women act differently? The answer is 'it depends'. However, the daily work of women and men take place against the backcloth of an embedded set of masculine beliefs and practices. Such behaviour is competitive, self-interested and about advancing one's career. We observe that male and female ministers and senior civil servants behave in the similar ways and those ways involves women 'managing like men' or, more precisely, measuring up to particular templates of culturally dominant masculinity. Many of the quotes in preceding sections are from women, although mostly you would not know. The quotes illustrate the argument of Wajcman (1999) and others that senior women are faced with severely constrained choices in organizations where 'the norm for the managerial occupation remains male', and women are still perceived to be the 'wrong sort of chap' (Watson 1994). In such circumstances women in, or aiming to secure, senior positions may need to 'practice masculinity' in order to be effective - or even intelligible (Britton 2000; Lovenduski 1998, 2005; Wacjman 1999). '[W]omen who have made it have done so by adopting the male model' and 'are still expected to "manage like a man"' (Wacjman 1999:15960). Thus, for the most part, men and women manage in similar ways; ways which are embedded in the inherited beliefs and practices about masculinity.

A vivid example of one woman's encounter with masculine practices is provided by Estelle Morris's resignation as Secretary of State for Education (for a full account of the observational fieldwork see Rhodes 2011, chapter 9). In her resignation letter, written in part by Alastair Campbell (the Prime Minister's Director of Communications), she said: 
I am good at dealing with the issues and in communicating to the teaching profession. I am less good at strategic management of a huge department and I am not good at dealing with the modern media.

She resented the media and the distress they caused:

Getting home Sunday night and the press had been on to friends wanting to know who you lived with, why you split up, things like that. At that time I needed my privacy. [Minister, TI]

She concluded, 'I don't think this is for me' (The Guardian 24 October 2002).

David Blunkett (2006: 404), her predecessor at Education, thought the crisis did not add up to a bag of beans and 'she got in a panic' but with many others saw her as:

the heroine (sic) of the moment - the honest politician, the person whom says 'I'm not up to it, the person who says, 'I liked my previous job but I don't have the strategic approach to manage this department.'

Above all he felt sorry for her:

how can your heart not go out to her and want to support her, as some of us have tried to do for the last two months, desperately trying to bolster her and having more confidence in her than she has in herself. (Blunkett 2006: 404)

Perhaps most significant for this article, he conceded that the Bull Elephant style was not an option for her: 'Yes, we were like Bull Elephants, because if you didn't stand up to [colleagues], they just held you in total contempt really.' [Minister, TI] We doubt there 
could be a clearer instance of the specific content of the masculine tradition, in which women manage.

But managing like a man is not the same as being an embodied man. There are constraints and potential gendered costs. For example, women must navigate the potential double bind whereby they face social sanctions for being either too masculine or too feminine (Jamieson 1996). Although it is important not to assume a false homogeneity among women, women have fewer culturally acceptable modes of authoritative leadership. Women face the additional cost of 'managing their gender', a problem that male leaders and managers seldom have to consider (Stivers 2002).

It is noteworthy that when we revisited the fieldwork, women - ministers, and civil servants alike - were more concerned about work-home balance than any male minister, Permanent Secretary or other official. Stories of homework, ferrying kids to the scouts, and making breakfast did not figure in any interview with a man. Although there was some evidence of changing roles in terms of reaction to long hours' culture of the departmental court, it was more striking by its rarity:

My partner is pregnant. We are expecting our first baby in a month and I knew that I wouldn't physically be able to do these hours and have a family. [APS, TI]

This was the only instance of a male official voicing concerns about family life. The silence may demonstrate the tenacity of the sexual division of labour. As Kelly et al. (2011, 283) observe male white-collar workers, even those who are involved fathers, are reluctant publicly to raise family responsibilities because of the strong beliefs that they should privilege professional identity above other ties and responsibilities. 
One female Minister described her routine as a madhouse interspersed with the 'rule' to her Private Office that:

'Monday evening I don't do, I just said to the office, 'Right Monday evening I go home, I see the children I come back for a 10:00pm vote.' Tuesday and Wednesday I do business dinners or whatever is needed, Thursday evening I go home after the 7:00pm vote and see the children, Fridays is constituency. [Minister TI]

One DS works 'say 9 am to 7 pm. I enjoy the job, I enjoy the work, I have no kids, I have a flexible husband'. [DS, TI]

This section illustrates the prosaic; the conflict between the newer expectations that women have about work and older expectations around family life. The phrase, 'I was juggling career and family life, [Permanent Secretary, TI] was repeated in some form or other by most women in this study and seldom if at all by men in the study. This long-standing conflict had not been resolved at the ministerial and permanent secretary level, where individuals have much control, let alone elsewhere in the departmental court or at lower levels in the departmental hierarchy.

It was only women who commented on the nigh irreconcilable demands between children and partners, and work; home versus the Greedy Court. Promoted early, one female civil servant reflected on the impact of her elevation to the greedy court:

It was a difficult decision for me. It was a 60+ hours a week job and would have major repercussions at home. My husband was proud of me, boasted of my achievements in public, but privately hated it. I believe he felt emasculated by my success. $[\mathrm{TI}]$ 
Contrast that experience, which ended in divorce, with the description of the long suffering but indulgent wife of a senior male civil servant.

She [his wife] keeps my feet on the ground. She has a good appreciation of the opinion of the 'man on the Clapham omnibus', and combines this with a healthy disrespect for anyone who gets too obsessed with their work. She's also fairly fed up by the fact that the career I've chosen is one often denigrated by Ministers and the press. And one where the relative pay has got lower and lower. She also regards it-fairly - as her role to make sure that what you might call the extramarital relationship I have with my job doesn't get out of hand. [TI]

Taken together, these two vignettes show how internal practices are also sustained by gendered beliefs and practices in the family. As such, the reform of the greedy court faces both internal and external sources which interact to maintain the gendered status quo.

Some women, both ministers and civil servants, argued that skills and experiences gained as parents in the private sphere were transferable to the public world of governance. For example one female Minister observed: 'it's nowhere near as bad as having small children. I tell you having babies is much the best training to be a Minister'. [Minister TI] On the one hand, these discussions could be seen as reinforcing gender stereotypes of caring as a natural feminine attribute. On the other hand, they challenge dominant understandings by asserting a positive link between skills gained from caring work and the exercise of political competence; characterizing care as a social practice rather than a natural feminine attribute (Mackay 2001). 
Women were also more likely to comment spontaneously on the existence of sexist behaviour. The women staff in the correspondence section of the court resented the way private secretaries routinely referred to them as 'corres girls' - seeing it as a derogatory term intended to undermine them. The sexist culture of other departments was also remarked on. For example, the Treasury was seen as 'a very controlling department, and more so than I remembered it from the 1970s.' [Minister, TI] It was said to have 'a laddish culture'. [Minister, TI].

Rhodes' (2011) original study does not cover the formal priority given to diversity and the relatively progressive equal opportunities policies of central government. For example, as the fieldwork began, the Gender Equality Public Service Agreement set formal targets to increase the number of female civil servants in the upper reaches of the service (Grades 6/7) and the Senior Civil Service (Durose and Gains 2007). It is perhaps surprising, therefore, that issues of gender equality policy were rarely mentioned. They cropped up only once during the fieldwork and then for only one meeting with one female (and feminist) minister on one day.

On the other hand, this relative silence is not surprising because it exemplifies the skill of the civil service at making formal gestures that translate policy only slowly into everyday practices. Gender reform is one of those policies; an example of 'dynamic conservatism' (Schon 1973). Permanent secretaries take their cue from Ministers. What is important to Ministers is important to the civil servants. One point to be drawn from this is that gender reforms are not a priority for most ministers, even female - and feminist - ministers, most of the time. Media commentators have observed that despite the 'warm words' and commitment by the Cabinet Office to improve diversity in the senior civil service, progress has been 'at a snail's pace'. 'Initiatives have withered on the vine [...] [or] run into the 
sand'. As one ex-senior civil servant remarked, 'the truth is that the top of the service, because it's overwhelmingly male, tends to self-perpetuate with a distinctly macho culture' (The Guardian Public Magazine, April 5, 2011).

\section{Conclusions: gender and the greedy court}

Focusing on every day practices to explore the inner life of public bureaucracies enables us to better understand how things work around here. We have demonstrated that fresh insights can be gained by applying a gender perspective to ethnographic data gathered for another purpose. There are few examples of ethnographic analysis in the study of British government elites and even fewer of gender. Most gender studies have been theoretical critiques of bureaucracy or studies of lower levels in the bureaucracy; for example, implementing equal opportunities policies. This study breaks new ground in casting light on the persistence of inherited beliefs and everyday practices that maintain gender inequality at the apex of government, where policy is made. Most public administration studies focus on recruitment and training. Our ethnographic study of gender and the departmental court seeks not only to encourage more ethnographic studies but also to start a fruitful dialogue between feminist political scientists and public administration scholars. Our ambition is to 'ground' the theoretical insights of the former with the analysis of everyday administrative practice by the latter. By so doing, we provide a new analytical lens for both.

At the start, we asked, how do the bureaucratic beliefs and practices of the greedy court reproduce gender relations, and what are the gendered consequences of such everyday practices? Our data show the day-to-day practices of the departmental court are premised on and reproduce gendered inequalities. The protocols and ritualized practices are best conceived as coping mechanisms through which the departmental court maintains 
continuity, and through which organizational change, notably equal opportunity reforms, can be adopted, adapted, and resisted. So, the status quo is not challenged. The comments on juggling family and career, sexism, marginalization, and managing like men demonstrate the slow pace of change. It is easy for such observations to be trivialized or passed off as unremarkable truisms. However, they demonstrate the continuing gender consequences of beliefs and practices, both internal and external, which continue to limit the opportunities and capacity for women and men to participate on an equal footing. Also, if these constraints on women operate at the apex of the bureaucracy, then there will be many more consequences at lower levels where individuals have much less autonomy. Finally, if the observation that the departmental court embeds gendered beliefs and practices and constrains women to 'adopt a masculine administrative identity or to accept marginalization in the bureaucratic hierarchy' (Stivers 2002:12) confirms what we already knew, then it is worth reflecting on the importance of that simple fact. The court is greedy and it consumes men and women in similar ways. But, after decades of equal opportunities reform, women, including senior women, still face greater obstacles, dilemmas and costs; plus ça change, plus c'est la même chose, thanks to tacit gender-specific practices and powerful informal rules (see also Waylen and Chappell forthcoming).

The idea of 'care' refers not only to individuals' caring responsibilities in the domestic sphere, but also to 'coping' work in bureaucracies, and to public policymaking issues about caring and the sustenance of society and individuals (for impact on street level bureaucracy see, Atkinson and Lucas 2012). Privileging the departmental court as a greedy institution means that all these facets of caring are neglected, undervalued and depoliticized. The daily beliefs and practices of the greedy court - hierarchy and bureaucratic politics; civility, neutrality and detachment; 
the gendered pattern of coping work; and loyalty and commitment to long hours' culture - all work together to reinforce particular sedimented and dominant forms of masculinity, and thus the gendered status quo. Although the numerical presence and positional dominance of men may have been challenged, that does not mean that particular beliefs and practices of masculinity have been undermined. Nor does it remove the different costs still paid by men and women in the greedy court. The conclusion reached by Watson in 1994 remains relevant in the 2000s; the civil service combines progressive formal equal opportunities policies and exclusionary beliefs and practices. Our findings reinforce the argument that changing policies is perhaps less important than challenging the gendered practices and culture (Kelly et al 2011) of greedy institutions, and the tenacity with which the long-hours' culture is seen to embody productivity, commitment, loyalty, public service and performance. 


\section{Acknowledgements}

The authors wish to thank the editors and three anonymous referees for their helpful comments and constructive criticism. Georgina Waylen, Louise Chappell, Francesca Gains, Claire Annesley and Martin Smith provided insightful feedback on earlier drafts. Funding from the British Academy/ Academy of the Social Sciences in Australia International Collaborative Programme and the University of Edinburgh School of Social and Political Science helped facilitate our collaboration. Earlier versions of the paper were presented at the Political Studies Association Annual Conference, London, 2011 and the University of Manchester Gender Research Network/ FIIN international symposium on The Core Executive and Gender, Manchester, 2011.

\section{References}

Agar, M. 1996, The Professional Stranger. Second edition. San Diego: Academic Press.

Annesley, Claire and Gains, Francesca (2010), 'The Core Executive: Gender Power And Change', Political Studies (1): 1-21.

Atkinson, Carol and Rosemary Lucas (2012), 'Policy and Gender in Adult Social Care Work', Public Administration DOI: 10.1111/j.1467-9299.2012.02040.x

Barber, Michael 2007. Instruction to Deliver. Tony Blair, Public Services and The Challenge of Targets. London: Politico's.

Bellavita, C. 1991. 'The public administrator as hero', Administration \& Society 23 (2): 186-193. 
Bevir, M. and Rhodes, R. A. W. 2003. Interpreting British Governance. London:

Routledge.

Bevir, M. and Rhodes, R. A. W. 2006. Governance Stories. Abingdon, Oxon.: Routledge.

Bevir, M. and Rhodes, R. A. W. 2010. The state as cultural practice. Oxford: Oxford University Press.

Billing, Y. D. 1994. 'Gender and Bureaucracies - A Critique of Ferguson's “The Feminist Case against Bureaucracy"”, Gender, Work \& Organization 1 (4): 179-193.

Bird, S.R. 2011. 'Unsettling the University's Incongruous Bureaucratic Structures: A Case Study Approach', Gender, Work \& Organization 18 (2): 202-230.

Blunkett, David 2006. The Blunkett Tapes. My Life in the Bear Pit. London: Bloomsbury.

Britton, D. M. 2000. 'The epistemology of the gendered organization', Gender \& Society 14 (3): 418-434

Campbell, Alastair 2007. The Blair Years. Extracts from the Alastair Campbell diaries. London: Hutchinson.

Chappell, Louise 2006. 'Comparing Political Institutions: Revealing the Gendered 'Logic of Appropriateness', Politics and Gender, 2 (2): 223-235.

Connell, R. W. 2002. Gender, Polity Press: Cambridge.

Coser, L. A. 1974. Greedy Institutions. Patterns of Undivided Commitment. New York: The Free Press. 
Crompton, R. Ed., 1999. Restructuring Gender Relations and Employment. Oxford:

Oxford University Press.

Duerst-Lahti G. and Kelly R. M. Eds, 1995. Gender Power, Leadership, and Governance. Ann Arbor, MI: University of Michigan Press.

Durose, Catherine and Gains, Francesca 2007. 'Engendering the Machinery of Governance.' In Annesley, C, Gains, F and Rummery, K, (Eds.), Women and New Labour: Engendering Politics and Policy, Bristol: Policy Press, 93-116.

Fenno, R. E. 1990, Watching politicians: essays on participant observation. Berkeley: Institute of Governmental Studies, University of California.

Ferguson, K. 1984. The Feminist Case against Bureaucracy. Philadelphia: Temple University Press.

Flyvbjerg, B. 2006. 'Five misunderstandings about case studies', Qualitative Inquiry 12 (2): $219-45$.

Fox, K. 2004 Watching the English. The hidden rules of English Behaviour. London: Hodder and Stoughton.

Franzway, S. 2001. Sexual Politics and Greedy Institutions. Annandale, NSW: Pluto Press.

Franzway, D., Court and R. W. Connell, Staking a Claim: Feminism, Bureaucracy and the State, London, Paladin, 1989

Geertz, C. 1973. The Interpretation of Cultures. New York: Basic Books.

The Guardian. 2011. 'Where are the female leaders of the future?' The Guardian Public Magazine, April 5. 
Hawkesworth, M. 2005 'Engendering Political Science: An Immodest Proposal', Politics \& Gender, 1: 141-156.

Hooper, C. 2001. Manly States: Masculinities, International Relations and Gender Politics. Columbia University Press.

Jamieson, K. H. 1996. Beyond the Double Bind: Women and Leadership. Oxford: Oxford University Press.

Kanter R. M. 1997. Men and Women of the Corporation. New York: Basic Books

Kelly, E. L., Ammons, S. K., Chermack, K. and Moen, P. 2011. 'Gendered Challenge, Gendered Response: Confronting the Ideal Worker Norm in a White-collar Organization', Gender \& Society 24 (3): 281-303.

Kenney, Sally J. 1996. 'New Research on Gendered Political Institutions', Political Research Quarterly, 49 (2): 445-466.

Lodge, G. and Rogers, B. 2006. Whitehall's black box: accountability and performance in the senior civil service. London: Institute for Public Policy Research.

Lovenduski, J. 2005. Feminizing Politics. Cambridge: Polity.

Lovenduski, J. 1998. 'Gendering Research in Political Science', Annual Review of Political Science, 1: 333-56.

Mackay, F. 2001. Love and Politics: Women Politicians and the Ethics of Care. London: Continuum.

Martin, Patricia Yancey 2006. Practicing Gender at Work: Further Thoughts on Reflexivity, Gender,Work and Organization, 13 (3): 254-276. 
Miller, K. \& McTavish, D. 2011. 'Women in Public Administration Scholarship', Public Administration 89 (2): 681-97.

Norton, P. 2000 'Barons in a Shrinking Kingdom: Senior Ministers in British

Government' in R. A. W. Rhodes Ed. Transforming British government. Volume 2.

Changing roles and relationships. London: Macmillan: 101-24.

Pringle, Rosemary 1989. Secretaries Talk: Sexuality, Power and Work. London: Verso

Ramsey, K. and Parker, M. 1992 'Gender, Bureaucracy and Organizational Culture' in M.Savage and A.Witz (Eds), Gender and Bureaucracy. Oxford: Blackwell: 253-274.

Rhodes, R. A. W., 2011. Everyday Life in British government. Oxford: Oxford University Press.

Rhodes, R. A. W. Paul 't Hart and M. Noordegraaf, 2009. 'So What? The Prospects And Pitfalls Of Being There', in R. A. W. Rhodes, Paul 't Hart and M. Noordegraaf (Eds.), The Ethnography of Government Elites: Up Close and Personal. Houndmills, Basingstoke: Palgrave-Macmillan, 2007: 206-33.

Savage, Michael and Witz, Anne . Eds. 1992. Gender and Bureaucracy, Oxford: Blackwell.

Schon, D. 1973. Beyond the Stable State. Public and Private Learning in a Changing Society. Harmondsworth: Penguin Books.

Scott, J. W. 1986. 'Gender: A Useful Category of Historical Analysis', The American Historical Review 91(5): 1053-1075.

Sjoberg, L. 2103. 'Feminism'. In Paul ‘t Hart and R. A. W. Rhodes (Eds.), The 
Oxford Handbook of Political Leadership. Oxford: Oxford University Press.

Stanley, M. 2008. How to be a Civil Servant @ http://www.civilservant.org.uk/. Last accessed 6 October 2009.

Stivers, C. M. 2002. Gender Images in Public Administration: Legitimacy and the Administrative State. Thousand Oaks, CA and London: Sage. Second Edition

Streeck, Wolfgang and Kathleen Thelen (Eds.) 2005. Beyond Continuity: Institutional Change in Advanced Political Economies. Oxford: Oxford University Press.

Terry, L. D. 1991. 'The Public Administrator as hero: All that glitters is not gold. Rejoinder to Christopher Bellavita's "The Public Administrator as hero", Administration \& Society 23 (2): 155-185.

Wajcman, J. 1999. Managing Like a Man: Women and Men in Corporate Management. Cambridge: Polity Press.

Watson, Sophie 1994. 'Producing the Right Sort of Chap: the Civil Service as Exclusionary Culture', Policy and Politics 22 (3): 211-222.

Wulff, H. 2002. 'Yo-Yo Fieldwork: Mobility and Time in Multi-Local Study of Dance in Ireland', Anthropological Journal of European Cultures 11: 117-36.

Yeatman, A. 1990. Bureaucrats, Technocrats and Femocrats. Essays on the Contemporary Australian State. Sydney: Allen \& Unwin.

Young, Iris Marion. 1987. 'Impartiality and the civic public', in S. Benhabib and D. Cornell (Eds). Feminism as Critique, Minneapolis: University of Minnesota Press: 57-76. 